\title{
Not Only Little Monsters: Diversity in Music Fandom in LGBTQ Lives
}

\author{
Marion Wasserbauer \\ University of Antwerp \\ marion.wasserbauer@uantwerpen.be
}

\author{
Alexander Dhoest \\ alexander.dhoest@uantwerpen.be \\ University of Antwerp
}

\begin{abstract}
This paper challenges common representations of LGBTQ (Lesbian, Gay, Bisexual, Trans* and Queer) music fans, broadening the scope by considering a variety of LGBTQ individuals and fandoms. With this aim, we discuss the narratives on "being a fan" in six life stories of self-identified LGBTQ individuals, who have participated in an oral history project on the role of music in LGBTQ lives. The analysis discloses a great diversity of what being a fan means, covering various intensities of fandom, how narrators conceptualize the topic in their own words, within their daily lives, and in relation to their sexual and gender identifications. These accounts further explore and move beyond established stereotypes of LGBTQ fandom, often focusing on extreme fans and specific fan objects, ${ }^{1}$ and instead indicate diversity on a number of continuums: from active to more passive fandom, from diva worship to participating in DIY cultures, from listening to making music, and from theoretical to emotional involvement.
\end{abstract}

KEYWORDS: fandom, LGBTQ, oral history interviews, identity, sexuality, everyday life

\section{Introduction}

Most of us are self-proclaimed fans of one artist or another, but what does this expression actually mean? And what have our sexual and gender identity got to 
do with it? In this paper, we approach fandom in LGBTQ (Lesbian, Gay, Bisexual, Trans* and Queer) individuals, reporting on a broader research project about music and identity in the lives of LGBTQ individuals, in which many narrators spontaneously addressed fandom. ${ }^{2}$ Within the narrators' life stories, collected through oral history interviews, the topic of being a fan arose naturally in a variety of ways. It is not surprising that discussions of fandom and the meanings of being a fan also emerge in music-related research that does not focus on fandom, as most individuals in contemporary society come across fandom in their daily lives. According to Zwaan et al. (2014: 2), "[i]t has become common sense that 'everybody is a fan of something'". Similarly, Sandvoss (2005: 3) states that (under the influence of new media) fandom became an ordinary aspect of life from the early 2000s. Even if - or especially because - some of our narrators would not immediately use the term fandom to describe their strong involvement with certain artists and genres, their stories broaden our understanding of fandom and its importance in LGBTQ lives.

LGBTQ is an umbrella term for an extremely diverse group of individuals who identify their sexuality as non-heterosexual and/or their gender as non-normative. Music as a cultural and social outlet is an important element in their lives, as their stories show. The focus on the individual's story allows for a situated interpretation of fandom embedded in each narrator's life, highlighting the diversity within this group and avoiding generalizations as often originate from single-object fandom studies. Hence, this paper moves beyond the study of singleobject fandom and towards a deeper exploration of music in relation to identity formation - two key issues in contemporary music fandom research according to Duffett (2013). We map a continuum of ways in which music (fandom) matters in everyday life, taking a close look at various instances of fandom and discussions of the meaning of "being a fan" within six narrators' life stories, exploring the different dimensions of fandom for LGBTQ individuals. The central questions guiding this analysis are: What fan-like activities and behaviours do these LGBTQs pursue, and what role do emotions and affect play within their fandom? Do they make connections between their fandom and their sexual and gender identity?

In order to do justice to the various (explicit and implicit) forms of fandom each narrator mentions, as well as their personal contexts, in this paper we discuss their stories separately rather than ordering the analysis thematically. Within each life story, we focus on two interrelated aspects of fandom. First, we look at the narrators' investments and involvements in fandom for a range of objects and genres, their reflections providing insights that single-object fandom research is often unable to provide. Second, we investigate the narrators' emotional involvement and their meaning making processes, discussing affective aspects of their fandom as connected to their sexual and gender identity.

\section{Music fandom and LGBTQs}

Most authors describe fandom as a strong affective involvement and emotional investment in particular cultural objects (for example, Harrington and Bielby 2005). In the same vein, Sandvoss defines fandom as "the regular, emotionally 
involved consumption of a given popular narrative or text" (2005: 8). More recently, Duffett (2014: 4) stated that although the Internet has transformed fandom, some elements remained the same: the fascination with music, various romantic and folk ideologies, the emphasis on a star system, the tendency of fans to form social communities, to pursue shared concerns, and to follow characteristic practices. Consequently, he defines contemporary music fandom as "a cultural conviction ... that combines a threshold of affective engagement with, variously or in combination, musical appreciation, music practice, celebrityfollowing, social networking, dancing, collecting, and self-expression" (2014: 7).

As these definitions convey, music fandom is closely linked to notions of the self and expressing one's identity, as is music more generally (see DeNora 2000; Frith 1996). Involvement with music is also connected to sexual and gender identities, which are indispensable and crucial (if not always the most central) aspects in the lives of LGBTQs. The connection between non-heterosexuality and music has been studied by sociologists of music and musicologists, in key volumes such as Queering the Pitch: The New Gay and Lesbian Musicology (Brett et al. 2006) and Sexing the Groove: Popular Music and Gender (Whiteley 1997). Often, this literature focuses on fans of specific artists (Jennex 2013), genres or scenes (Leibetseder 2012; Taylor 2012), or phenomena like the Eurovision Song Contest (Heller 2007; Lemish 2004).

As Dyer notes, "lesbian and gay male subcultures have been linked, though often only tangentially", but they "are not one" (2004 [1987]: 138). Gay men are often associated with a camp taste and the worship of extravagant divas. Thus, Farmer notices that "female star adoration or, as it is more commonly known in queer contexts, 'diva worship' has been a vital staple of gay male cultural production, where it has sustained a spectacularly diverse array of insistently queer pleasures" (2005: 169). In The Queen's Throat, Koestenbaum (1994) explores opera diva worship of gay men. Two decades later, based on interviews with gay male Lady Gaga fans, Jennex (2013: 343) asserts that the veneration of female icons and cross-gender identification are still relevant within the gay community. Contrary to the gay predilection for camp and divas, queer female music research has often focused on participation and community rather than pure fandom, investigating, for example, the riot grrrl movement (Downes 2012; Leonard 1997), "womyn's" music festivals or "celesbians" (Taylor 2013).

In this paper, we build upon this literature by discussing both male and female narrators, but rather than focusing on their strongest objects and practices of fandom, we discuss the full width of each individual's music preferences and listening habits. In this way, our research responds to the recent call to pay attention to everyday practices of media consumption instead of spectacular subcultural styles (Osgerby 2004: 136), and to explore how we can "access and explore fan-related experiences that are less obviously interpreted as fan activity" (Hassan 2014: 58). Along these lines, Hassan (2014) researches hidden fans and their practices, while Sandvoss and Kearn (2014) stress the importance of everyday, ordinary fandom. The Janissary Collective speaks about "fannish behavior" (2014: 77), highlighting that there is a plurality of fandom, not only the highly visible aspects and practices. ${ }^{3}$ To them, 
[t] he difference between "ordinary" audience members and fans is a matter of degree rather than kind. What media fans do, how they engage with a text, is an expansion and extension of (what we understand to be) typical receptive practices. (The Janissary Collective 2014: 78)

\section{Methodology}

The cases discussed in this paper are a selection out of 22 oral histories collected in 2014 and 2015 by the first author among a wide variety of LGBTQ individuals. The call for participation was advertised online, on Facebook and in paper in various LGBTQ locations in Flanders. While all the participants in this project discussed fandom and fan-related activities to some degree, the two femaleidentified and four male-identified individuals discussed in this paper were selected because they talked spontaneously and extensively about the matter of fandom in their life. The age of the narrators ranges from 18 to 41 years, with one narrator pursuing vocational training as a hairdresser, three working in the artistic field, one having obtained a PhD and working in the academic field, and one being a librarian having obtained several degrees. The narrators could choose between either a pseudonym or their real first name. ${ }^{4}$

In preparation for the interview, the prospective participants were asked to think about music in their life as an LGBTQ individual: when was music important, why, how, and what music did/do they listen to? They were also encouraged to look at their diaries, photographs, CD collections, musical memorabilia and personal playlists to help them think about the topic. ${ }^{5}$ During the interview, they were encouraged to tell their own story with the interviewer intervening as little as possible. Accordingly, most narrators prepared (musical) memorabilia and music to listen to. If necessary, an openly visible topic list around music and identity was used to stimulate the talk. The interviews discussed here lasted between 65 and 160 minutes, with one interview being recorded in two sessions at the narrator's request (Anna).

All interviews were transcribed by the first author and analysed by both authors, paying special attention to narratives related to fandom. All excerpts of the interviews were translated from Dutch by the authors. In accordance with the tradition of oral history research and in order to respect each narrator's story, in our analysis we take a holistic approach sustaining the connections between each person as a whole and their specific narratives on fandom.

\section{Dario: a little monster's story}

Dario is 18, identifies as male and gay, and lives with his mother in a mediumsized Flemish city. He trains as a hairdresser and dreams of moving to Antwerp, the biggest Flemish city. The genres he listens to are pop, hip hop and rap, and the artists he likes are almost exclusively female. His iPhone is an important tool for his fandom, as it contains all his music and photos of him and his idols, which are key achievements in his fandom. His interview had a clear focus on being a fan of Lady Gaga, and, to a lesser extent, of Nicki Minaj and Kesha. 
Dario calls Lady Gaga his biggest idol, explaining that for him there is a difference between just liking the music of an artist and the artist actually being an idol. His fandom means a lot to him and he expresses a "you only live once" attitude, travelling and spending a lot of money on his divas. He does not mind skipping school to visit Gaga concerts abroad or working in order to pay for meet and greets. Dario also collects objects related to his idols, in particular perfumes by Nicki Minaj and Lady Gaga, some of which he even orders from abroad. Clearly, Dario is happy to spend a lot of time, money and effort on his idols, in particular Lady Gaga. He is even prepared to get a tattoo related to their shared birthday:

I designed a small tattoo, well, not very Gaga related, ... it's simply the Zodiac sign of Aries, with a triangle in the background, but slightly finer. Uhm and the dream is then, if I ever meet her, that she writes down "March 28th" and I would have that tattooed in her handwriting, underneath.

He describes this tattoo as his "goal of the moment" in his Gaga fandom, referring to a recurrent idea of fandom "goals". The ultimate goal is to reach the "full circle" of fandom for his idols: seeing their shows, meeting them, getting an autograph and being followed by them on Twitter.

Dario is also part of a Gaga fan community, in a secret Facebook group called "Belgian Little Monsters". From the beginning of her career, Lady Gaga emphasized that fans are essential to her and created an enormous following of what she calls "Little Monsters". The collective experience and sense of belonging together is very important, and media such as the secret Facebook group reinforce this experience. Being part of this community also entails social pressure concerning "good fandom", as Dario repeatedly mentions. For example, it is necessary to restrict the amount of idols one admires: "I... I really like of all of them a lot, but it's not like... [silence] you know, you can't have too many idols, otherwise you don't seem serious any more". Although referring to a different genre and period, this statement echoes Koestenbaum's diva manifesto, disclosing a clear parallel between pop idol adoration and opera diva veneration:

The opera queen must choose one diva. The other divas may be admired, enjoyed, even loved. But only one diva can reign in the opera queen's heart; only one diva can have the power to describe a listener's life, as a compass describes a circle. (Koestenbaum 1994: 19)

Koestenbaum then laments how difficult this is and describes his own allegiances with about a dozen divas.

Throughout the interview, it becomes clear that Dario feels strongly about Lady Gaga and his fellow fans. These emotions are conveyed in his style of narrating and choice of words. For example, he recounts being "so jealous" because one member of the Little Monster group managed to see Gaga at the airport while he did not. This made him very angry at himself, but also at Lady Gaga: "I was so angry at her that I didn't listen to her for three days". The way Dario talks about her bespeaks a parasocial relationship: he feels close to her, as if he knows her in person. Both Click et al. (2013) and Bennett (2014) found similar strong 
identifications with Lady Gaga, as her strong media presence and personal communication via Twitter give her fans a sense of personal connection.

For Dario, this connection also extends to his sexual orientation:

It's also, well, it was in the first year of secondary school [age 12-13], when she started her career, and that was also the moment, well, a bit later, I also started to come out about my sexuality, so. Well, that creates a sort of bond.

Yet again, this biographical connection confirms that Gaga's importance in Dario's life is not limited to music; her persona and social messages deeply influence his life. More generally, Dario connects Gaga to homosexuality on two levels. First, Lady Gaga's explicit engagement for the LGBTQ community is one of the reasons he enjoys and admires her so much: "Well yes, that's also something... she is famous for her... fight against, well, for gay rights, so yes, she is somebody I look up to". Second, Dario notes that straight men are not that likely to be Gaga fans, drawing on his experiences with the online group of the Belgian Little Monsters, where many male fans came out as gay after some time. Dario links this to Lady Gaga's extravagance but also her staying true to herself, and of course to her active engagement in gay rights. This echoes Jennex' (2013: 350) findings that Gaga shapes the everyday life of some fans and changes the way they understand themselves as gay males, drawing on Gaga's persona and discourse to develop and perform identities. Like Dario, in his research many fans report that they became more out and flamboyant after becoming Gaga fans (2013: 350). Dario's story confirms Jennex' findings that young gay males are still in need of and actively engaging with female divas and camp (2013: 343) and that " $[\mathrm{t}]$ his extreme fandom offers gay men confidence, community and, for some, the hope to envision a better future (2013: 357-358). Hence, we conclude that Dario's experiences, although unique (as any fan's), clearly parallel those disclosed by other Gaga fandom research, as well as the broader literature on gay men's veneration of idols or divas.

\section{Pieter: serial diva worshipping across genres}

Pieter is a music theatre dramaturge aged 31, who is professionally involved in the opera world. He describes his sexuality as gay, and himself as being rather feminine. He realized early in life that he was gay and started to come out around the age of 15 or 16 , but had a difficult time with his mother upon his first (involuntary) coming out and left home aged 18. Just like with Dario, the emphasis in the interview with Pieter lies on female performers. However, he calls them divas instead of idols and the genres he discusses are more varied, ranging from pop and opera to country.

In the very beginning of the interview, Pieter states that he has been thinking about his own and other gay men's fascination with divas like Céline Dion and Madonna:

I asked myself what it could mean, uhm... because it's often the gays, isn't it, who love women ... - very glamorous women, naturally, and everything 
surrounding them, and well: are those mother traumas? And then I thought: is it identity formation in gays?

It is striking that divas are Pieter's first association when thinking about music and homosexuality. He recounts that aged 12 or 13, the film Titanic was released, and Céline Dion became his great diva until a teacher introduced him to Maria Callas at 15 or 16: "Maria Callas became the diva, I've got all her biographies here, and I have two large [artworks]... All she... all she ever recorded, I've got it on CD, so [laughs]". Collecting all things Callas is surely a sign of his admiration and fandom. He mentions that her Hollywood glamour intrigued him, but also "the tragic life around her, with Onassis - it's not only the music itself, but uhm, her whole appearance, actually".

Like Pieter, many fans of Maria Callas report a fascination with her voice, glamour and grace on the one hand, and the passion and tragedy in her life on the other. Koestenbaum, for instance, describes his interest in Callas as part of his sexual and cultural identity and states that she "remains the operatic diva most closely ... related with gay fandom" (1994: 135). In fact, Pieter read Koestenbaum's The Queen's Throat years ago, and leafing through his copy during our interview, a section he annotated struck us: "Did I love her? Or did I envy her?" (1994: 18). These questions connect to Pieter's fascination for Callas and his general interest in the connection between music, divas, gender and homosexuality. He ruminates on his own teenage experiences of not feeling at ease with himself, being skinny and awkward and angry at his family, and then making a connection to "super strong women, the huge volume and singing and so on; that is something you look for then, I guess". Pieter expresses that divas were able to compensate his own insecurities and give him a sense of empowerment. Moreover, apart from his own story, he feels there is a sort of natural connection between gay men and divas within different musical genres, but he cannot quite pinpoint exactly what it means.

One of the most striking features in Pieter's story is his serial obsession with stars:

It always happens that I am obsessively engaged in one thing. Sometimes that might be just one song or one aria or so. Afterwards [that is: after Callas] ... I was about 20 or so, and stood in line with my boyfriend and best girl friend to meet Cecilia Bartoli, I've got a photo in my kitchen.

These obsessions embrace very diverse musical genres. After starting with pop divas Britney Spears, Madonna and Céline Dion as an early teenager, Pieter moved on to explore opera diva Maria Callas and, later on, Cecilia Bartoli. So, while Dario's interview disclosed parallels between pop and opera diva fandom, Pieter's shows that these are not distinct fields of fandom, but can be combined in one person. In his early twenties, he went on to discover country stars Dolly Parton and Johnny Cash and started admiring Elvis Presley. Rap and hip hop are other genres Pieter enjoys. Remarkably, he sees a close connection between rap and opera, stating that both genres pick out feelings and biographical events as a central line and render these in dramatized and enlarged ways. He appreciates the aggression and power in the music of, for example, Eminem or Nicki Minaj, 
and talks about it in similar terms as Alban Berg's Wozzeck and Luigi Nono's Prometeo: "It cuts so deep... I can't describe it any other way. It is so hard, that it really ... it gives me gooseflesh".

When asked whether he would call himself a fan of the divas mentioned above, Pieter answers decidedly: "Yes yes, of course, yes yes yes". Similarly, he frequently uses verbs and adjectives expressing an intense involvement with and experience of music: he speaks about going into "trance", experiencing "magical moments", getting carried away by the music, and "overwhelming" experiences. Throughout various genres, Pieter describes experiences of being star-struck and of catharsis through musical performances. His first pop concert ever, Britney Spears' Onyx Hotel tour, left him speechless, thinking "this is paradise, really". Interestingly, he parallels this with being deeply touched by Wagner's opera Siegfried, "even if that is on a wholly different level, that it still has something ... that you go into a trance, almost". Pieter is convinced that music is able to change a person and alter one's mental state, as it really touches us. Both professionally and privately, Pieter is much more interested in the emotional impact of music than in its technical properties. When asked about the link between certain music and his identity, he sees a close connection:

The diva stuff we talked about, but also the pop music, the janettenmuziek ${ }^{6}$ [laughs], that's what I love to dance and act silly to and then, well, the very hurt, aggressive, biographical within music, well, yes, that is connected to my identity, yes.

As with Dario, his story contains some features of what is traditionally considered to be typical of fandom, for example, collecting all available records of Callas, reading biographies, and asking Bartoli for a photograph after a concert. Echoing the definitions of fandom in the literature review, a strong emotional and affective dimension characterizes his fandom throughout his eclectic music taste, as he seeks and finds identification. His experiences are in line with what Harris describes as two features that lie "at the very heart of gay diva worship": "the almost universal homosexual experience of ostracism and insecurity" and the desire to "elevate [one]self above [one's] antagonistic surroundings" (1997: 10; quoted in Farmer 2005: 169). Throughout his story, Pieter compares his own experiences to that of other gay men, confirming a shared cultural practice and Farmer's claim that diva worship is a staple of gay culture (2005: 169). To these insights, Pieter's interview adds that pop, hip hop and opera diva fandom are not only similar but can also be combined, as part of broader patterns of taste which remain hidden in research focusing on single objects of fandom.

\section{Anna: a female perspective on divas}

Anna is a 27-year-old woman who describes her sexuality as "predominantly lesbian". She tells that music and women are the two great loves of her life, so this interview felt very special to her. Anna realized that she was different in her teen years and thought she would be forever alone, until she met her first big love in her late teens. 
An outstanding feature of Anna's interview is her musical and general artistic focus on the past. As she puts it herself,

I actually did nothing that was contemporary. I didn't listen to contemporary music much, always classical and times long gone; I only read old books, I only watched old films. I was inside a completely nostalgic thing.

Some of the genres and periods she appreciates are classical instrumental music, political and lesbian songs from the German Weimar Republic era (1920s), French chansons from the 1930s and 1940s, and Nina Hagen's 1980s punk. Anna states that she has a "nostalgic spirit" which this music of times long gone speaks to. Talking about these periods, Anna uses plenty of expressions highlighting her intense, fannish engagement with the music, describing herself as a "diehard fan" or "super fan" of certain artists, "wild about", "completely into" and even "in love" with certain singers, in particular Maria Callas.

A central theme unifying her eclectic taste in music is the strong emotional connection to music. As Anna describes, she went through a period of loneliness and isolation as a teenager, caused by her sexual orientation and the lack of other feminine lesbians to identify with. Music was the most important consoling factor for her: "Music could always arouse and simultaneously appease a desire - a very strange process of catharsis". Discovering Maria Callas, for example, touched her deeply, since she was able to identify with her music and tragic life:

I can never separate an oeuvre from a life, for me that is something that belongs together. So, I heard her voice and started to listen to her CDs and I was totally wild about it, and then I started to discover her life, and I found that so incredibly tragic, and I recognized myself so intensely in her sorrow, the loneliness and the complete sacrifice for love, which she did have, and a sort of - yes, an immense idol-thing started between that woman's voice, which is so vibrant and so powerful and which contains all the passion of the world, and then knowing that she actually experienced this in her life, and that in my opinion, she actually more or less died from lovesickness - yes, that was just, for me that was... I recognized myself so much in it, and I... I could really imagine that I would also die for love, or commit suicide for love, or rather because of loneliness.

In the same period, she also became acquainted with Greta Garbo, who became a major figure in her lesbian identification: Through Garbo, Anna realized that she was not the only feminine lesbian in this world. She found her "absolutely incredibly fascinating" and was simultaneously identifying and in love with her.

In her discovery of music through time, Anna encountered many more musical idols and aspects she identified with. For instance, both the openly lesbian French singer and actress Suzy Solidor, famous in the Paris scene during the 1930s, and German Kabarett singer Claire Waldoff, most famous in the 1920s, attracted her attention. Anna is a fan of both women, although she does not necessarily like Waldoff's rough singing voice, but is rather attracted by the political and critical dimensions of her music, as well as her openly lesbian attitude. When it comes to Solidor, Anna remarks that one feels the pathetic tone in her voice, a loneliness and a certain impossible desire. Anna is aware that her taste in music is rather 
unique, being intensely fascinated by the singers' lives as well and showing a special interest in their gender and sexual identity, defining this as a sort of "gay" taste.

Anna's fandom is clearly not limited to music but also connected to her personal life and politics. For instance, her interest for music of the Weimar Republic era is rooted in the political and gender bending notions of that period. She mentions that women dressed and behaved like men, undermining traditional gender roles: "I actually really listened a lot to that music because the lyrics were good and sharp and satirical and full, really full of lesbian undertones". She sums up that all the music she ever liked is linked to "that idea of freedom and controversy and rebellion ... Not always per se with a lesbian undertone, but always something... yes, against the current, and for freedom, in one way or another, whether it is political or intimate or..."

Although this political edge sets Anna apart from the narrators discussed so far, her adoration of Maria Callas is certainly a form of diva worship in line with that of Pieter. The description of her adoration of Callas and Garbo, as well as her selfdeclared later "Piaf obsession" resemble the swooning for divas by gay men as described by Koestenbaum (1994) or Dyer (2004 [1987]): the glamour these divas exude as well as their tragic lives seems to not only fascinate many gay men, but also some lesbian women. This is in line with Pearl, who scrutinizes diva adoration and suggests to "dismiss the notion that opera fanaticism is the province of gay men only" (2015: 49). Women are often excluded from the discourse on diva adoration, which reinforces the common conception of gay male diva worshippers. Just like Pieter, Anna is simultaneously in love with Callas and idolizing her, recognizing herself in her adored diva.

\section{Mostafa: adoring Arab divas}

Mostafa, a Belgian citizen with a Moroccan background, is 41 and describes his sexuality as gay. Most of what we talk about during the interview is heavily influenced by Arab culture and his family community. After speaking about identity, Arab identity and gay identity for about an hour, we turn to music. Mostafa starts the topic by telling about Om Kalsoum, the big diva of classic Arab music: "Yes you see, I'll tell you one thing, really... Every Arab from Morocco to Iraq grew up, and not just us: our parents, our grandparents... That music has lasted for generations, that's Om Kalsoum". His statement immediately clarifies that Om Kalsoum is not only celebrated within the gay community, but is admired by a transnational, mainstream Arab audience. Just like Dario, Pieter and Anna, Mostafa has detailed knowledge about this diva's music and life, and he emphasizes that "nobody has been able to equal her".

While his swooning reminds of the typical gay diva worship discussed above, for Mostafa admiring Om Kalsoum is not connected to his sexual identity as much as his Arab identity. An anecdote he recounts literally connects the singer to his Arab identity: after a period of not being interested in Arab music as a young man, he rediscovered a record by Kalsoum at his mother's place. Taking a closer look at the record sleeve, he found pen scribblings on it and suddenly remembered 
that this must have been the first Arabic word he has ever written in the late 1970s: "So I went over the record sleeve, and I wrote, not knowing what the letters meant, I drew over them with a pen. So that is also my rediscovery, that's really bizarre - my first words of Arabic". The words he traced on the sleeve were "Om Kalsoum".

Although Mostafa asserts that most individuals of Arab origin are fans of Om Kalsoum and other great Arab singers, he also feels that gays especially react to these divas. He recounts talking about Barbra Streisand and other Western gay divas with a friend recently:

And I said "that's remote from me, I'm not gay, in that respect I'm not gay", until I caught myself, that in Arabic music... I really am ... And he also thought about this, how does it come? I really don't know.

When asked whether he considers himself as a fan of Om Kalsoum, Mostafa affirms: "yes, naturally", adding that he feels that in order to become a fan of someone, they have to be an established "monument" in his culture. Clearly, fandom takes on yet another meaning here: beside being expressed through a strong involvement with a diva and connected to sexual identification, for Mostafa fandom also carries a strong cultural meaning. This cautions against a narrow focus on the connection between music fandom and a single aspect of identity, such as sexuality. Instead, we should be attentive to the multiple and intersecting social positions informing and being informed by fandom, in this case also ethniccultural identity.

\section{Stefaan: indie fandom}

Stefaan is a man of 33 who describes his sexual orientation as gay. Music takes up a central position in his life, which is why he offered to do this interview. To support his story, he fetched a notebook which he kept from when he was a teenager, and we listened to various songs during the interview. Stefaan enjoys introducing people to new music and has a soft spot for archiving and structuring music in the form of mix CDs, playlists, and "best of" lists. As he stresses, music in itself is very important in his life, independent of being a fan of specific musicians. Music has started to play a role early in his life: "Music was one of the first things that gave me an identity when I was 16-17. In the sense that: I was rather good and mainstream, but I sensed that music gave me an identity on the one hand, but on the other hand also a passion". Stefaan also links key moments of his LGBTQ identity to music. When he was 17 or 18 , a male friend he really liked took him to see a theatre play involving gay characters. Jeff Buckley's "Love As the Young Ones Do" was part of the soundtrack, and this song is unforgettable for Stefaan. After seeing the play, he made a note in his notebook: "Well, the end is near and the new beginning is awaiting me". This (musical) moment signifies a change in his attitude towards his sexuality, coming out as bisexual and, eventually, as gay.

Stefaan describes developing a real passion for music. The emotional characteristics and effects of music especially attract him and of all music genres, indie touches him most: "I can really get gooseflesh watching a show and 
experiencing that intensity". Certain types of male voices enable a particularly close connection to the musician, which Stefaan enjoys immensely. He names Sean Carey and Sufjan Stevens as artists who manage to evoke these feelings of connection and affection in him: "If I hear that I feel like cuddling that guy". Bonenfant explores this phenomenon of queer vocal timbres, explaining that " $\mathrm{t}$ ] imbre carries connotations of touch through its relationship to the notion of texture. (...) It is layered, multi-faceted and rich with complexity and information" (2010: 75).

Elaborating on the connection between music and identity, Stefaan describes: "So music became identity in different ways: personal identity, but also social identity". In his own words, he reflects what Hesmondhalgh describes, namely that music "represents a remarkable meeting point of the private and public realms, providing encounters of self-identity (this is who I am; this is who I am not) with collective identity (this is who we are; this is who we're not)" (2008: 239). An example of both his personal and social identity being connected to music can be found in Stefaan's various musical alter egos on online platforms, his nicknames throughout the years referring to songs or artists, most recently "Sufjanboy", referring to Sufjan Stevens, and "Indieboy". To Stefaan, these alter egos prove "how important music was in the way I presented myself". Concerning his gay identity, Stefaan mentions another two important songs and videos that intrigued him and made him aware of his gay identity: Skunk Anansie's "Secretly", depicting flirtations between a girl and two boys, and Sigur Rós' "Viðrar vel til loftárása", in which two young boys kiss.

In the interview, Stefaan introduces the concept of fandom himself, describing it as "that one step further" to just liking an artist. He sketches how his fandom evolved over the years: when he was younger, he was a fan of many bands at the same time. Showing a densely packed scheme of all shows he wanted to see forty in total, all ranked and rated afterwards - at a music festival in the early 2000s, he uses the word "maniacal" to describe his obsession with music. He clearly remembers a concert of Radiohead when their music had just taken a more electronic turn, at which point he expressed his fandom through buying band T-shirts and posters (one of which still features in a frame on his wall), as well as making an email-address referring to them.

At the time of the interview his fandoms focuses on a few select musicians, in particular the American singer-songwriter Sufjan Stevens. He expresses his fandom through a broad range of activities such as checking Sufjan Stevens' blog daily, using a Sufjan screensaver at work, collecting articles on the artist, and buying his records:

I also buy his records while I already have his CDs, collecting as much as possible. And swooning over Sufjan [laughs]. Going to his shows, for instance shortly in Luxembourg. I would not got to Paris or Luxembourg for many artists, but I do for Sufjan. So that's fandom to me.

This excerpt discloses Stefaan's attitude towards his own fandom. First, there is a clear parasocial relationship: whenever he talks about Sufjan Stevens, he simply calls him "Sufjan" and it feels as if they are very close. Second, his attitude is somewhat ambiguous: he is very serious about it, following Stevens closely 
through online media and liking to showcase his fandom. Yet, when he talks about swooning over Stevens, his voice mocks the exaggeration "swooning" seems to imply, and his laughter also indicates a hint of shame.

What is interesting about Stefaan is that he discloses a strong, worship-like attachment to indie artists occupying a very different position in the musical spectrum as the pop and opera divas discussed above and in academic literature. Again, this interview highlights the diversity of LGBTQ fandoms, as well as their non-exclusive nature. Stefaan's interview also illustrates how the link between music fandom and sexuality, while important, is not necessarily clear or explicit. Just like the other narrators discussed above, he shows a great interest in his favourite artist as a person as well as a musician, but the link with his sexuality is less straightforward. Stevens does not disclose a whole lot about his private life, he is neither explicitly gay or straight. While being gay and highlighting the importance of music to his identity, Stefaan enjoys the ambiguity in songs by Stevens that do not address men or women explicitly, but instead leave things in the middle.

\section{Nina: DIY and riot grrrl sounds}

Nina is 32 and identifies as lesbian/queer. Next to her job as a librarian and archivist, she is interested in feminism, gender studies and music. In the interview, Nina provided a glimpse into feminist and queer music scenes and communities. A large part of our talk focused on riot grrrl, a network or movement of women protesting the misogynist and heteronormative character of alternative music scenes, emerging in the USA in the early 1990s and subsequently spreading all over the world (Leonard 1997). Nina is one of the co-founders of Ladyfest in Belgium, an alternative punk, rock and grunge festival for women, featuring women only or mostly female bands. She also plays the guitar in her own band, one of the only Belgian female-only crust bands, a sound Larkin (2009) describes as blending "elements of metal, hardcore and punk with uncompromising political lyrics".

Nina's feminism and involvement with queer, punk and squatting scenes has shaped her identity and influenced her musical tastes. While she is deeply involved in a particular music scene, she is not a fan of specific artists. Therefore, her music consumption, participation and admiration works differently from what we have seen with the previous narrators. Nina's story represents that of a queer DIY community often overlooked in fan studies, since they do not engage in typical fan activities or self-identify as fans. We would argue, however, that Nina's story testifies to the fluidity of audience, participation and fan research, as her intense everyday life engagement with music touches on all these fields.

Nina owns several posters of bands and Ladyfests she talks about, as well as Tshirts and plenty of CDs and cassettes. When asked whether she would consider herself to be a fan of these bands, she answers:

Hmmm, as such yes, but I don't see it that way... Yes, that's sort of... I think within the riot grrrl, queercore, punk-crust scenes it is like - you are a fan, but you also participate. You are part of... So it's not like: your idol is on stage and you watch it and you buy stuff, and you just consume, or you're 
passively admiring, but you also... You can start your own band or your own zine and you can write about the shows or start a record label, organize shows...

Nina describes a rather activist interpretation of fandom which has a DIY character and involves active participation, as opposed to fandom focussed merely on consumption. Consequently, the music scenes she is part of do not only centre on music or musicians, but are all about the community that forms around them and the activities connected to them. These activities involve, for example, hosting fellow bands, making zines, travelling to Ladyfests around Europe, cooking for the participants, maintaining squats, learning to play instruments and searching for fellow female musicians to form a band. Two other important concerns are keeping the events affordable and accessible, and minimizing the distance between the audience and the musician, literally and figuratively, as also highlighted in other research on riot grrrl culture (for example, Downes 2012). There is a strong feminist tendency in Nina's music listening and making. She remarks that most of her CDs are by female artists, who have always been especially intriguing to her: "That's even cooler, when a woman makes music! I don't know, I think it's both: it's extra nice to listen to, but it's also an incentive to make things yourself".

Beside this primary interest in female musicians, she also has an interest in queer music, which is linked to her lesbian/queer identity, for example queercore. Taylor (2012: 126) describes queercore as akin to punk, "distinguished by its loud, fast and raw sound, its physically energetic and interactive performance style, and ... its lyrics", which are "queercentric, remorselessly vulgar, antagonistic and political, relying heavily on a balanced mix of both anger and humour". Nina particularly appreciates the fact that queercore musicians were rather androgynous; "it was okay to break with gender norms; I enjoyed that". In general, Nina sees a strong connection between music and her identity: "I think the music I mostly listen to is very strongly connected to my identity. Because it is a lot of feminist music, much queer music and much DIY music... yes. I don't know, politically inspired things...".

For Nina, music does not only function as entertainment and in relation to individual identity. Rather, music, lyrics, genre, musicians and production are political dimensions protesting heteronormative, androcentric and misogynist norms. Crust and anarcho-punk are traditionally male or "masculinist" music genres (Downes 2012); a standard which is undermined by the female-only approach to the genre. Generally, the riot grrrl movement attempted to challenge "conventional standards of hetero-femininity; including challenges to beauty standards, competition for male approval, Whiteness, heteronormativity, sexual double standards, and consumerism" (Downes 2012: 210). Nina's story ticks all these boxes. Compared to other narrators, Nina speaks less about her personal emotions connected to the music. However, identification with music is essential for her on a more structural level, criticizing societal norms. Despite her strong, fan-like involvement in a particular scene, both the genres she likes and the active ways she participates set her apart from the other narrators and what is typically considered fandom. 


\section{Conclusion}

One of our aims was to explore the various forms of sustained and affective consumption of and engagement with music among LGBTQs. Sticking to Sandvoss' basic definition of fandom as "the regular, emotionally involved consumption" (2005: 8) of popular text, such as music, we conclude that all narrators discussed here are "fans". More specifically, we took a special interest in how the fans' sexual and gender identities influences what music they are fans of, and vice versa. Our findings show that in the lives of our narrators, the mutual interaction of identity and music is very important.

Addressing our first research question, concerning the fan-like activities and behaviours these LGBTQs pursue and the role emotions and affect play within their fandom, we can conclude that the narrators reported a lot of "fannish behaviors", to employ the Janissary Collective's term (2014). Many fan activities were spontaneously discussed: from less involved expressions of fandom such as going to concerts and buying records, to more engaged forms such as collecting albums or (signed) pictures, merchandising and paraphernalia, or following blogs and Twitter accounts, becoming part of fan communities, visiting meets and greets, and even considering a tattoo. While such activities do not generally distinguish our narrators from straight fans, they do bespeak a strong and emotional attachment to music which accompanies them in their everyday lives and identity formation. Often - but not always - their idols are strong female divas. Former research of gay communities and fandom often focussed on gay male diva worship, and the discussion of divas by various narrators certainly affirms that this focus is justified. However, we argue that there are more nuances to diva worship than have previously been acknowledged. Focussing not on one single star but examining the meaning of diva fandom throughout different ages, musical genres, cultures and genders, it becomes clear that for each narrator, their diva has a very specific meaning in relation to their sexual identity. Anna's story, for example, shows that diva worship is not at all limited to male opera queens, and Mostafa's story draws attention to the position of divas in Arab culture. Farmer argues that "[m]ost critical discussions of gay diva worship posit in some fashion that gay men engage divas as imaginary figures of therapeutic escapism" (2005: 169). In our case, not the researchers but the narrators themselves made connections between their personal and emotional life and their engagement with various divas. Various narrators reported recognizing themselves in, and at the same time, being in love with their adored stars. Again, this phenomenon occurs throughout genres.

This brings us to the second research question, concerning the connection between fandom and sexual and gender identity. Most narrators report close links between the music they appreciate and their personal identity. Although not all of them immediately report clear links with their sexual identity or the queer community, a heightened awareness of gender and sexuality dimensions within the music and the artists emerges. Dario most closely matches the clichéd profile of the gay fan, connecting Lady Gaga - a contemporary embodiment of the pop diva archetype - to both his own sexual identity and the broader gay community. Pieter combines a more cerebral approach, reflecting on and theorizing gay men's diva worship and homosexuality, with a strong emotional investment in various 
divas across musical genres. Like Pieter, Anna sees her sexual and gender identity as inextricably linked to music and performers, and she shares his admiration for Maria Callas amongst other female singers. However, she lives this fandom in a private and emotional way, not participating in any conventional forms of fandom. While the first three narrators connect their fandom to their sexual and gender identity, Mostafa sees a closer link between his favourite diva and Arab culture. Nonetheless, he does recognize a parallel with Western gay diva worship. Stefaan further complicates the picture: while he strongly connects his fandom to his coming out process and sexual identity, its object is not situated in pop or classical singing but in indie music. Finally, Nina's lesbian/queer sexuality and feminism are closely linked to the music she appreciates, but she considers herself more as a participant than a fan. She is part of highly interactive and subversive DIY communities which aim to "trouble the distinction between audience and performer" (Downes 2012: 222), bespeaking an engagement with music which is more oriented towards creation than consumption. Whether they recognize themselves in their idols, find strength and positive messages through them, or are drawn to a certain queer timbre or appearance, all narrators connect their own experiences of being lesbian, gay, or queer to the music they enjoy. Music fandom actively facilitates the formation and expression of their sexual and gender identity.

As a whole, these interviews confirm but also complicate the body of knowledge on LGBTQ music fandom. While many statements echo earlier findings, what became apparent is the diversity of fandom within this "community", both in terms of objects, activities and affects of fandom, and in terms of connected sexual and gender identifications. By considering a diverse range of individuals and not focusing on a single genre or artist, a more complex and nuanced view on LGBTQ fandom emerges: LGBTQs can venerate multiple idols, serially or simultaneously, in different genres; some gay men are fans of pop divas and some prefer opera divas; some like both while some like neither; queer women can have similar or more alternative tastes, questioning the rather clearcut genre and gender division sketched in the literature review. Other divisions such as education or cultural identity further complicate the picture, so we think it is crucial for any future research to further explore these intersections between music and identities, doing justice to the diverse and idiosyncratic forms of music fandom rooted in everyday lives.

\section{Endnotes}

1 "Fan object" is a term from fan studies, meaning the text or hero (for example, the Beatles) that forms the focus of a fan's passion.

2 This project is funded by the Research Programme of the Research Foundation Flanders (FWO) and by the University Research Fund (BOF) of the Flemish Government.

3 "Fannish" is a term from fan studies also defined by Duffett (2013: 293) as "pertaining to fandom".

${ }^{4}$ This research has been approved by the Ethical Committee of the University of Antwerp in 2014 (reference: SHW_14_11_02). 
${ }^{5}$ The playlists and musical memorabilia accompanying the interviews can be accessed at www.queervoices.be.

${ }^{6}$ Dutch for "faggot music."

\section{Acknowledgments}

We would like to thank the narrators who generously shared their stories and made this article possible.

\section{References}

\section{Bibliography}

Bennett, L. 2014. Fan/Celebrity Interactions and Social Media: Connectivity and Engagment in Lady Gaga Fandom. In L. Duits, K. Zwaan and S. Reijnders Eds. The Ashgate Research Companion to Fan Cultures. Farnham: Ashgate: 109120.

Bonenfant, Y. 2010. Queer Listening to Queer Vocal Timbres. Performance Research 15 (3): 74-80.

http://dx.doi.org/ 10.1080/13528165.2010.527210

Brett, P. et al. Eds. 2006. Queering the Pitch: The New Gay and Lesbian Musicology. London: Routledge. Second edition.

Click, M. et al. 2013. Making Monsters: Lady Gaga, Fan Identification, and Social Media. Popular Music and Society 36 (3): 360-379. http://dx.doi.org/10.1080/03007766.2013.798546

De Nora, T. 2000. Music in Everyday Life. Cambridge: Cambridge University Press.

Downes, J. 2012. The Expansion of Punk Rock: Riot Grrrl Challenges to Gender Power Relations in British Indie Music Subcultures. Women's Studies 41 (2): 204-237. http://dx.doi.org/ 10.1080/00497878.2012.636572

Duffett, M.2013. Understanding Fandom: An Introduction to the Study of Media Fan Culture. New York: Bloomsbury. 2014. Introduction. In M. Duffet Ed. Popular Music Fandom: Identities, Roles and Practices. London and New York: Routledge: 1-15.

Dyer, R. 2004 [1987]. Heavenly Bodies: Film Stars and Society, London and New York: Routledge.

Farmer, B. 2005. The Fabulous Sublimity of Gay Diva Worship. Camera Obscura 59 (20-2): 165-195. http://dx.doi.org/10.1215/02705346-20-2_59-165

Frith, S. 1996. Music and Identity. In S. Hall and P. Du Gay Eds. Questions of Cultural Identity. London: Sage: 108-127. 
Harrington, C. L. and Bielby, D. D. 2005. Flow, Home, and Media Pleasures. The Journal of Popular Culture 38 (5): 834-854.

http://dx.doi.org/10.1111/j.0022-3840.2005.00144.x

Harris, D. 1997. The Rise and Fall of Gay Culture. New York: Hyperion.

Hassan, N. 2014. Hidden Fans? Fandom and Domestic Musical Activity. In M.

Duffett Ed. Popular Music Fandom. Identities, Roles and Practices. London and New York: Routledge: 55-70.

Heller, D. 2007. t.A.T.u. You! Russia, the Global Politics of Eurovision, and Lesbian Pop. Popular Music 26 (2): 195-210.

http://dx.doi.org/10.1017/S0261143007001237

Hesmondhalgh, D. 2008. Towards a Critical Understanding of Music, Emotion and Self-identity. Consumption, Markets \& Culture 11 (4): 329-343.

http://dx.doi.org/ 10.1080/10253860802391334

Jennex, C. 2013. Diva Worship and the Sonic Search for Queer Utopia. Popular Music and Society 36 (3): 343-359.

http://dx.doi.org/10.1080/03007766.2013.798544

Koestenbaum, W. 1994. The Queen's Throat: Opera, Homosexuality and the Mystery of Desire. New York: Vintage Books.

Larkin, C. 2009. Amebix. In Encyclopedia of Popular Music. Oxford: Oxford University Press. Fourth edition.

http://dx.doi.org/10.1093/acref/9780195313734.001.0001

Leibetseder, D. 2012. Queer Tracks: Subversive Strategies in Rock and Pop Music. Farnham: Ashgate.

Lemish, D. 2004. "My Kind of Campfire": The Eurovision Song Contest and Israeli Gay Men. Popular Communication 2 (1): 41-63. http://dx.doi.org/10.1207/s15405710pc0201_3

Leonard, M. 1997. "Rebel Girl, You Are the Queen of My World": Feminism, "Subculture" and Grrrl Power. In S. Whiteley Ed. Sexing the Groove: Popular Music and Gender. London and New York: Routledge: 230-255.

Osgerby, B. 2004. All the Young Dudes: Media, Subculture and Lifestyle. In B. Osgerby Ed. Youth Media. London and New York: Routledge: 107-144.

Pearl, M. B. 2015. The Opera Closet: Ardor, Shame, Queer Confessions. Prose Studies 37 (1): 46-65.

http://dx.doi.org/10.1080/01440357.2014.984915

Sandvoss, C. 2005. Fans: The Mirror of Consumption. Cambridge: Polity.

Sandvoss, C. and Kearns, L. 2014. From Interpretive Communitites to Interpretative Fairs: Ordinary Fandom, Textual Selection and Digital Media. In L. Duits, K. Zwaan and S. Reijnders Eds. The Ashgate Research Companion to Fan Cultures. Farnham: Ashgate: 91-106.

Taylor, J. -

2012. Playing it Queer: Popular Music, Identity and Queer World-making. Bern: Peter Lang.

2013. Lesbian Musicalities, Queer Strains and Celesbian Pop: The Poetics and Polemics of Women-Loving-Women in Mainstream Popular Music. In S. Baker, A. Bennett and J. Taylor Eds. Redefining Mainstream Popular Music. London and New York: Routledge: 39-49. 
The Janissary Collective. 2014. Fandom as Survival in Media Life. In L. Duits, K. Zwaan and S. Reijnders Eds. The Ashgate Research Companion to Fan Cultures. Farnham: Ashgate: 77-90.

Whiteley, S. 1997. Introduction. In S. Whiteley Ed. Sexing the Groove: Popular Music and Gender. London and New York: Routledge: xiii-xxxvi

Zwaan, K. et al. 2014. Introduction. In L. Duits, K. Zwaan and S. Reijnders Eds. The Ashgate Research Companion to Fan Cultures. Farnham: Ashgate: 1-6.

\section{Interviews}

Anna. 2014/15. Interview by Marion Wasserbauer, Flanders, 10 October 2014 and 9 January 2015.

Dario. 2014. Interview by Marion Wasserbauer, Flanders, 13 November. Felix 2015. Interview by Marion Wasserbauer, Flanders, 22 October. Mostafa. 2015. Interview by Marion Wasserbauer, Flanders, 31 August. Nina. 2014. Interview by Marion Wasserbauer, Flanders, 8 December. Pieter. 2014. Interview by Marion Wasserbauer, Flanders, 12 October. Stefaan. 2014. Interview by Marion Wasserbauer, Flanders, 8 September. 